\title{
Explicit and Implicit Learning Ability of Children with Reading Disabilities Seen through the Task of Artificial Grammar Learning
}

\author{
Ye Ji Park, Young Tae Kim \\ Department of Communication Disorders, Ewha Womans University, Seoul, Korea
}

Correspondence: Young Tae Kim, PhD Department of Communication Disorders, Ewha Womans University, 52 Ewhayeodae-gil, Seodaemun-gu, Seoul 03760, Korea

Tel: $+82-2-3277-2410$

Fax: +82-2-3277-2122

E-mail: youngtae@ewha.ac.kr

Received: October 5, 2015

Revised: November 28, 2015

Accepted: December 9, 2015

This article is based on a part of the first author's master's thesis from Ewha Womans University (2015).

This work was supported by the BK21 plus funded by the Ministry of Education of Korea.
Objectives: Recently, concern with cognitive processing ability has led to view reading as a multiple process where explicit learning and implicit learning are interrelated. The present study investigated whether children with reading disabilities (RD) and typically developing children (TD) show difference in explicit learning ability and implicit learning ability, and whether these abilities correlate with cognitive processing abilities related to reading by group. Methods: The study included $20 \mathrm{RD}$ in the 3rd-4th grade of elementary school and 20 TD matched with the former group in terms of chronological age and gender. Both groups of children were selected after undergoing Korean Wechsler Intelligence Scale for Children-III (K-WISC-III) and Test of Reading Achievement \& Reading Cognitive Processes Ability (RA-RCP). The study conducted the test of Artificial Grammar Learning (AGL). The AGL tasks consisted of two tasks: 'Perfect Free Recall' to measure explicit learning ability and 'Grammaticality Judgment' to measure implicit learning ability. Results: Both explicit learning ability and implicit learning ability of RD were lower than those of TD. The correlation between cognitive processing abilities related to reading and explicit/implicit learning ability varied depending on the group as well. Conclusion: Lower explicit learning ability of $\mathrm{RD}$ seems to be related to memory deficit and the absence of effective learning strategies. Lower implicit learning ability of RD supports the presupposition that the reading difficulties of these children are related to deficits in cognitive functioning.

Keywords: Artificial Grammar Learning (AGL), Reading disability, Explicit learning ability, Implicit learning ability
정상적인 읽기 발달 과정은 크게 '낱말 재인(해독)’과 ‘읽기 이해 (독해)'로 설명할 수 있다. 낱말 재인 능력은 인쇄된 문자를 인식하 여 음운적인 변환 혹은 철자 패턴을 거쳐 낱말로 전환하는 능력을 말하고, 읽기 이해 능력은 낱말이나 문장, 담화의 의미를 획득하여 평가, 판단, 추론 등의 보다 고차원적인 사고과정으로 나아갈 수 있 는 능력을 말한다. 낱말 재인과 읽기 이해는 서로 상호작용하며, 두 과정 중 어느 하나라도 문제가 생기면 ‘능숙한 독자’로 나아가지 못 하게 된다.

전통적으로 읽기장애는 낱말 재인에 어려움을 보이는 좁은 의미 의 ‘난독증'과 전반적인 읽기에 제한을 보이는 '읽기학습장애'의 두 가지 범주로 나누어졌으며(Kim, 2014), 아동의 읽기 성취도를 통해
장애 여부를 판별하고는 했다. 하지만 최근의 연구 경향은 단순히 읽기 성취도를 통해 읽기장애를 판별하는 것에서 벗어나, 읽기 관 련 인지처리능력을 읽기장애의 유의미한 예측 요인으로 보고하고 있다. 한 연구(Kim, 2013)에 의하면 현재까지 선행연구를 통해 밝 혀진 읽기 관련 인지처리능력은 자모지식, 음운인식, 빠른 자동 이 름대기, 음운기억, 통사처리, 듣기이해, 어휘 등이며, 이와 같은 인지 처리능력의 결함을 토대로 '단어인지 읽기장애', '읽기유창성 읽기 장애', ‘읽기이해 읽기장애’의 3 가지 유형으로 읽기장애를 분류할 수 있다.

여러 선행연구에서는 읽기가 명시적인 학습과 암묵적인 학습의 복합적인 토대 위에 습득되는 능력임을 주장하였다(Sperling, Lu, 
\& Manis, 2004). 명시적인 학습이란 학습자가 능동적으로 학습에 대한 의지를 가지고 지식을 습득함을 의미한다. 명시적인 학습 상 황에서 학습자는 학습의 목표를 달성하기 위해 의도적인 노력을 기 울이고, 자신이 학습할 내용을 선택할 수 있으며, 어떠한 정보를 습 득하고 있는지 명확하게 인식할 수 있다. 반면, 암묵적 학습이란 학 습자가 자신도 의식하지 못하는 사이 지식을 반복적으로 접하는 상황에서 자동적으로 학습이 이루어짐을 의미한다. 즉, 암묵적 학 습은 학습자가 학습을 위해 의도적인 노력을 기울이지 않고 자신 이 학습하고 있다는 것을 인식하지도 못한다는 점에서 수동적이며 비선택적인 학습이라 할수 있다.

읽기에서 명시적 학습은 어린 아동이 철자와 음소 사이의 관계 를 확립해가는 과정으로 설명된다. 어린 아동이 성공적으로 단어 를 해독하기 위해서는 단어가 자음과 모음 같은 음소들로 쪼개어 지고 음소들이 조작될 수 있다는 지식, 즉 음운인식(phonological awareness)이 선행되어야 하며, 더불어 각각의 음소가 특정 철자와 대응할 수 있음을 아는 철자 지식(letter knowledge)을 갖추어야 한 다(Pavlidou \& Williams, 2014). 이러한 초기의 철자법과 음운체계 사이의 연결이 명시적인 학습이라면(Harm \& Seidenberg, 2004), 읽기에서의 암묵적 학습은 해독에서의 자동성 확립으로 설명할 수 있다. 아동은 철자법에 대한 교수를 명시적으로 받지 않았음에 도 불구하고, 문자를 반복적으로 접하면서 점차 단어 내의 규칙성 을 무의식적으로 습득하게 된다. 아동이 의식하지 못하는 사이 습 득된 '철자법 규칙성(orthographic regularities)', '문자소-음운 규 칙성(graphophonological regularities)', '문자소-형태소 규칙성 (graphomorphological regularities)' 등이 암묵적 지식에 해당하 며, 충분한 암묵적 지식의 축적은 아동으로 하여금 의식적인 노력 을 기울이지 않아도 쉽게 읽기를 수행하는 '읽기의 자동화를 가능 하게 해준다(Gombert, 2003). 많은 규칙성을 포함하는 쓰기 체계 또한 암묵적 학습이 작용하는 영역으로, 실제로 아동의 철자에 관 한 연구들은 아동이 명시적으로 학습하지 않은 '어휘 철자법 규칙 성(lexical orthographic regularities)'에 능숙하다는 점을 보여준다 (Gombert, 2003).

현재까지 읽기장애 군의 명시적인 학습능력과 암묵적인 학습능 력에 대한 연구는 주로 영미권에서 다루어졌다. 보편적인 비언어적 학습능력이 근본적인 읽기 체계를 중재할 수 있다는 관점(Nicolson \& Fawcett, 1999; Stein, 2001)이 대두되면서, 일반 아동과 읽기 장애 아동의 암묵적인 학습능력을 비교하는 연구가 수행되었다. 암묵적 학습에서 읽기장애 아동의 수행력이 떨어진다면 아동이 보 이는 읽기의 어려움은 단순히 언어적 학습능력의 결함뿐만 아니라 비언어적 학습능력의 결함으로도 설명할 수 있기 때문이다. 실제로
문자소-음소 대응(grapheme-phoneme correspondence)에 관한 지식(명시적 지식)을 측정하는 표준화된 음운 검사에서 정상 범주 의 수행력을 보인 난독증군이 읽기유창성을 확립하지 못한다는 사 례들이 보고되면서 (Sperling et al., 2004), 읽기장애 군이 읽기에 보 이는 어려움의 기저에는 보편적인 비언어적 학습능력의 결함이 존 재할 가능성이 제시되었다(Nicolson \& Fawcett, 1999).

암묵적 학습능력을 살펴보기 위한 연구는 주로 연속 반응 시간 (serial reaction time, SRT), 통계적 학습(statistical learning, SL), 인 공 문법 학습(Artificial Grammar Learning, AGL)을 통하여 이루 어졌으며, 읽기장애 아동의 암묵적 학습능력에 대해 상이한 연구 결과가 나타났다. 연속 반응 시간(SRT)은 학습자가 학습 상황을 인 식하지 못하는 상황에서 반복적으로 제시되는 자극을 보고 무의 식적으로 학습이 이루어져 자극에 대한 반응 시간이 단축되는지 를 살펴보는 과제이다. 일반적으로 화면을 보고 제시되는 자극에 해당하는 버튼을 누르는 방식으로 실시되기 때문에, 시각과 운동 의 협응이 요구되는 과제라 할 수 있다. 통계적 학습(SL)은 별다른 지시나 강화가 주어지지 않는 상황에서 특정 입력 자극이 인접한 입력 자극에 연속해서 발생할 수 있는 전이확률을 학습자가 탐지 할 수 있는지 알아보는 과제이다.

Vicari, Marotta, Menghini, Molinari와 Petrosini (2003), 그리고 Jiménez-Fernández, Vaquero, Jiménez와 Defior (2011)은 연속 반 응 시간 과제를 사용하여 읽기장애 아동의 명시적 학습능력과 암 묵적 학습능력을 일반 아동과 비교하는 연구를 수행하였다. 두 연 구 모두 두 가지 조건으로 실험 과정을 구성하였다. 첫 번째 조건에 서는 제시되는 자극의 순서를 의식적으로 학습하지 않은 상황에서 아동의 반응 시간을 기록하여 암묵적인 학습능력을 측정한 반면, 두 번째 조건에서는 제시되는 자극의 순서를 의식적으로 기억하는 명시적인 학습을 거친 후 그 정보를 사용하여 과제를 수행하는 상 황에서 아동의 암묵적인 학습능력을 측정하였다. 실험 결과, 명시 적 학습이 포함된 상태에서 암묵적인 학습능력을 측정한 두 번째 조건에서는 읽기장애 아동의 수행력이 일반 아동과 비교해서 유의 한 차이가 없었지만, 명시적 학습 없이 암묵적인 학습능력을 측정 한 첫 번째 조건에서는 읽기장애 아동의 수행력이 일반 아동에 비 해 손상된 것으로 나타났다. 이러한 결과는 읽기장애 아동이 암묵 적 학습이라는 특정한 영역에서 결함을 보이며, 명시적으로 학습 된 지식이 읽기장애 아동의 암묵적 학습능력의 향상을 뒷받침했 을 가능성을 시사한다. 한편, Kelly, Griffiths와 Frith (2002), 그리고 Roodenrys와 Dunn (2008)은 앞서 제시한 연구와는 상반된 주장 을 하였다. 연속 반응 시간 과제를 사용하여 연구를 수행한 결과, 두 연구 모두 읽기장애 아동의 암묵적 학습능력은 손상되지 않은 
것으로 나타났다. 이러한 대조적인 결과는 읽기장애 아동의 암묵 적 학습능력이 연속 반응 시간 과제의 속성(언어성, 비언어성)과 난 이도 등에 따라 영향을 받아 다른 결과가 나올 수도 있음을 시사하 며, ‘읽기' 과정과 보다 유사한 암묵적 학습 과제를 실시해야 할 필 요성을 야기한다.

연속 반응 시간(SRT)이 반복적으로 제시되는 자극의 순서에 대 한 기억의 활성화를 요구하고, 통계적 학습(SL)이 입력 자극 사이의 전이확률에 대한 친밀도를 살펴본다면, 인공 문법 학습(AGL)은 반 복적으로 제시되는 자극을 통해 내재된 규칙성을 탐지하고 새로운 자극에 그 규칙성을 적용할 수 있는 능력을 가지고 있는지 확인하 는 과제이다. 연속 반응 시간과 통계적 학습이 모두 훈련 구간에서 학습하는 자극과 이후 암묵적 학습이 이루어졌는지 테스트하는자 극이 동일하다는 점에서 공통점을 지니지만, 인공 문법 학습은 학 습된 규칙성을 새로운 자극에 적용한다는 점에서 앞서 언급한 두 과제와차이가 있다. 또한 인공 문법 학습(AGL)은 과제를 수행하는 과정이 읽기의 자동화 과정과 유사하다는 점에서 암묵적 학습능력 과 읽기 능력의 관련성을 연구하기에 적합한 것으로 여겨진다.

인공 문법 학습(AGL)은 훈련 구간과 검사 구간으로 이루어지는 데, 먼저 훈련 구간에서 명시적 학습능력을 측정하기 위한 완전 자 유 회상(Perfect Free Recall, PFR) 과제를 실시한다. 완전 자유 회상 은 본래 기억상실 환자의 명시적 지식을 측정하기 위해 종종 실시하 던 자유 회상(free recall)을(Schacter, 1992) 수정한 과제이다(Pavlidou et al., 2010). 자유 회상이 단서 제공 없이 학습했던 자극을 가 능한 많이 기억해내도록 한다면, 완전 자유 회상은 대상자가 학습 자극을 빠짐없이 모두 기억해야 한다는 점에서 차이가 있다. 검사 자는 대상자에게 인위적인 문법 규칙을 토대로 구성된 문자열을 제 시한 후, 대상자가 문자열을 기억해서 그대로 재현할 때까지 이 과 정을 반복한다. 대상자가 의식적으로 문자열을 기억하려 노력해야 한다는 점에서 완전 자유 회상은 명시적 학습능력을 측정하는 과 제이다. 이후 검사 구간에서는 암묵적 학습능력을 측정하기 위한 규칙성 판단(grammaticality judgment) 과제를 실시한다. 검사자 는 대상자가 훈련 구간에서 보았던 문자열에 내재되어 있는 규칙성 을 파악했는지 알아보기 위해 훈련 구간과 같은 규칙을 적용한 문 자열과, 같은 규칙을 적용하지 않은 문자열을 무작위로 보여준다. 대상자는 새롭게 제시되는 문자열을 보고 훈련 구간에서 보았던 문자열과 같은 규칙이 사용되었는지 아닌지를 판단해야 한다. 앞서 훈련 구간에서 문자열에 내재된 규칙성을 알아내야 한다는 점을 검사자가 명시하지 않았기 때문에, 대상자는 의식적으로 인지하지 못하는 상태에서 문자열의 규칙성을 학습한 것이며, 이러한 규칙성 에 대한 판단 능력이 곧 암묵적 학습능력으로 여겨진다.
따라서 문자소와 음소, 문자소와 형태소 등 다양한 요소 사이의 복잡한 규칙성을 습득하고 그러한 규칙성이 암묵적으로 내재화되 어 자동화에까지 이르는 과정이 정상적인 읽기 발달의 과정임을 고 려할 때, 인공 문법 학습 과제와 읽기의 전반적인 인지적 처리 과정 이 내재된 규칙성을 추론한다는 점에서 일치함을 알 수 있으며, 인 공 문법 학습 과제를 통하여 읽기장애 아동의 암묵적 학습능력을 측정하는 것이 가장 적합하다 할 수 있다. 인공 문법 학습 과제가 '규칙 항목'과 ‘불규칙 항목’으로 이루어져 있다는 점 또한 읽기장 애 아동이 규칙성과 불규칙성 중 어느 영역에서 더 취약함을 보이 는지 파악할 수 있도록 해준다. 게다가, 인공 문법 학습의 완전 자유 회상 과제는 읽기장애 아동과 일반 아동의 주의집중력(attention) 과 집행기능(executive function)의 차이가 암묵적 학습능력에 영 향을 미칠 가능성을 통제할 수 있다는 점에서(Rüsseler, Gerth, \& Münte, 2006) 두 집단 아동의 암묵적 학습능력의 차이를 보다 정 확하게 비교할수 있다.

인공 문법 학습 과제를 사용하여 읽기장애군의 명시적 학습능 력과 암묵적 학습능력을 측정한 선행연구의 결과는 다음과 같다. Pavlidou, Kelly와 Williams (2010)은 연속 반응 시간 과제를 사용 한 선행 연구 결과들의 불일치가 단순한 암묵적 학습 메커니즘에 기인할 수도 있음을 지적하며, 더 복잡한 통계적 규칙성을 탐지하 는 인공 문법 학습 과제를 활용하여 읽기장애 아동의 암묵적 학습 능력을 측정하고자 하였다. 따라서, Knowlton과 Squire (1996)에서 개발한 실험 문법 1 (experiment grammar 1)을 토대로 약간의 수 정을 가하여 인공 문법 학습 과제를 구성하였다. 연구 결과, 읽기장 애 아동의 명시적 학습능력은 온전하였지만, 암묵적 학습능력이 일반 아동과 비교하여 유의한 정도로 손상된 것으로 나타났다. 반 면, Rüsseler 등(2006)은 성인 읽기장애 군과 정상 군을 대상으로 암묵적 학습능력을 살펴보기 위해 연속 반응 시간 과제와 인공 문 법 학습 과제를 사용하였다. 연구 결과, 읽기장애군과 정상군 모두 명시적인 학습능력과 암묵적인 학습능력에서 유의한 차이가 나타 나지 않았다. 이와 같이, 읽기장애 아동과 성인을 대상으로 인공 문 법 학습 과제를 실시한 연구를 정리하면 첫째, 읽기장애군의 명시 적 학습능력은 온전하며, 둘째, 연령에 따라 암묵적 학습능력에 차 이가 나타날 수도 있음을 시사한다.

성인의 언어 학습은 명시적인 학습을 토대로 이루어지는 경우가 많으며, 명시적인 기억 능력이 언어 학습의 성취도를 예측할 수 있 게 해주는 요인이다(Baik, Lee, Kim, \& Lee, 2012). 비록 아동의 언 어 학습에서 성인에 비해 명시적 학습의 영향이 감소되기는 하지 만, 그것이 명시적 학습이 중요하지 않음을 나타내는 것은 결코 아 니다. 문자소-음소 대응(grapheme-phoneme correspondence)에 
대한 명시적인 학습은 아동이 읽기에 필요한 도구를 갖추는 과정 에서, 특히 자동적인 읽기를 가능하게 하는 암묵적 지식이 충분하 지 않은 경우에 필수적이다. 또한 충분한 암묵적 지식을 갖춘다 하 더라도, 학습하지 않은 단어를 읽어야 하는 등의 상황에서 아동이 의식적으로 읽기를 통제하기 위해서는 명시적 지식이 있어야 한다 (Gombert, 2003). 이런 점을 고려할 때, 선행연구에서 읽기장애 아 동과 일반 아동의 명시적 학습능력이 유의하게 다르지 않았다는 연구 결과(Jiménez-Fernández et al., 2011; Pavlidou et al., 2010; Vicari et al., 2003)는 의문을 야기한다. 더불어, 읽기장애 아동의 명시 적 학습능력 및 암묵적 학습능력과 관련하여 인공 문법 학습 과제 를 이용한 연구 결과가 부족하므로(Pavlidou et al., 2010, 2014), 읽 기장애 아동이 보이는 특성을 이해하기 위해 연구가 더욱 진행될 필요가 있다.

읽기장애 아동은 읽기 성취도와 더불어 각 아동이 지닌 인지처 리능력의 결함을 토대로 판별될 수 있다. 또한, 명시적 학습능력 및 암묵적 학습능력은 직접적인 읽기 성취도는 아니지만 읽기에 전제 되는 인지적 능력에 해당한다. 따라서, '인지'라는 공통분모를 가지 는 명시적 학습능력 및 암묵적 학습능력과 읽기 관련 인지처리능 력의 상관관계를 살펴보는 것은 읽기장애를 이해하는 데에도 도움 이 될 것으로 생각된다. 현재까지 진행된 연구를 살펴보면, 명시적 학습능력은 어휘와 유의한 상관이 있는 것으로 나타났으며(Kidd, 2012; Ullman, 2004), 암묵적 학습능력은 단어읽기(Arciuli \& Simpson, 2012; Howard, Howard, Japikse, \& Eden, 2006), 통사론 지식 (Kidd, 2012; Ullman, 2004), 어휘(Evans, Saffran, \& Robe-Torres, 2009), 문법 등의 장기간에 걸쳐 습득되는 복잡한 언어 지식(Conway, Bauernschmidt, Huang, \& Pisoni, 2010; Yim \& Windsor, 2010) 과 유의한 상관이 나타났다. 하지만 '읽기에 관여하는 인지처리능 력'과 ‘명시적 학습능력 및 암묵적 학습능력’ 모두 비교적 최근 들 어 대두된 연구 주제라는 점을 고려하면, 현재까지 둘 사이의 상관 을 살펴보는 연구는 미미한 실정이다.

따라서 본 연구에서는 인공 문법 학습 과제를 실시하고 얻은 측 정값을 활용하여 읽기장애 아동과 일반 아동의 명시적 학습능력 (완전 자유 회상 과제 수행력) 및 암묵적 학습능력(규칙성 판단 과 제 수행력)에 유의한 차이가 나타나는지 살펴보았다. 더불어, 각 집 단의 읽기와 관련된 인지처리능력(자모지식, 빠른 자동 이름대기, 음운기억, 통사처리, 듣기이해, 어휘)이 명시적 학습능력 및 암묵적 학습능력과 어떠한 상관관계를 가지는지 알아보았다.

\section{연구 문제}

본 연구의 연구문제는 다음과 같다.
1) 읽기장애 아동 집단과 일반 아동 집단은 인공 문법 학습의 ‘완 전 자유 회상(PFR)' 과제에서 수행력에 유의한 차이를 나타내는가?

2) 읽기장애 아동 집단과 일반 아동 집단은 인공 문법 학습의 '규 칙성 판단(grammaticality judgment)' 과제에서 수행력에 유의한 차이를 나타내는가?

3) 읽기장애 아동 집단과 일반 아동 집단에서 읽기 능력 관련 변인 (자모지식, 빠른 자동 이름대기, 음운기억, 통사처리, 듣기이해, 어휘) 과 명시적학습능력 및 암묵적 학습능력은 어떠한상관을 보이는가?

\section{연구 방법}

\section{연구대상}

본 연구를 위하여 서울 및 경기도 지역의 초등학교에 재학 중인 3,4 학년 읽기장애 아동 20 명 $(8 ; 3-10 ; 9$, 남 10 명, 여 10명)과 성별, 학 년 및 생활연령을 일치시킨 일반 아동 20명(8;6-10;10, 남 10명, 여 10 명), 총 40 명이 참여하였다. 모든 아동은 연구 참여에 대해 보호 자로부터 동의를 받은 경우에만 연구대상자로 선정되었다.

\section{읽기장애 아동}

본 연구를 위한 읽기장애 아동의 선정 기준은 읽기 성취 및 읽기 인지처리 능력 검사(RA-RCP; Kim, Kim, Hwang, \& Yoo, 2014)에 서 명시한 기준을 따랐으며, 절차는 다음과 같았다. (1) 서울 및 경 기도 지역에 있는 초등학교 3-4학년 아동 중 부모 혹은 교사로부터 읽기가 유창하지 못하거나 읽기 이해력이 낮고 학업성취능력이 부 진한 아동을 추천받았다. (2) 부모 혹은 교사 면담을 통하여 시각 및 청각 등의 감각장애, 지체장애, 행동 및 정서장애, 확실한 신경학 적 결함이 있다고 보고된 아동은 제외하였으며, 기타 환경적인 요 인(다문화 가정)의 영향을 받는 아동도 제외하였다. (3) 추천받은 아동 중 한국 웩슬러 아동 지능 검사(K-WISC-III; Kwak, Park, \& $\mathrm{Kim}, 2001)$ 검사 결과 동작성 지능지수가 70 이상인 아동을 선정하 였다. (4) 읽기 성취 및 읽기 인지처리 능력 검사(RA-RCP; Kim et al., 2014) 결과 단어인지 읽기장애, 읽기유창성 읽기장애, 읽기이해 읽기장애 중 하나 이상에 해당하는 아동을 읽기장애 아동으로 최 종 선정하였다. 선정된 아동의 읽기장애 유형은 중복 읽기장애 13 명, 단어인지 읽기장애 3 명, 읽기유창성 읽기장애 3 명, 읽기이해 읽 기장애 1 명이었다.

\section{일반 아동}

일반 아동은 읽기장애 아동과 같은 지역의 초등학교에 재학 중인 아동을 대상으로 학년과 성별, 생활연령이 일치한 아동을 모집하였 
Table 1. Participants' characteristics

\begin{tabular}{lcc}
\hline & $\mathrm{RD}(\mathrm{N}=20)$ & $\mathrm{TD}(\mathrm{N}=20)$ \\
\hline Chronological age (mo) & $111.30(7.48)$ & $113.20(7.15)$ \\
K-WISC-III (nonverbal intelligence) & $93.65(10.87)$ & $108.65(11.63)$ \\
RA-RCP & & \\
$\quad$ Reading achievement score & $72.40(11.94)$ & $109.80(8.21)$ \\
$\quad$ Reading cognitive processes ability score & $82.15(7.45)$ & $109.05(12.25)$ \\
Gender (male:female) & $10: 10$ & $10: 10$ \\
Grade (3rd:4th) & $14: 6$ & $14: 6$ \\
\hline
\end{tabular}

Values are presented as mean (SD)

$\mathrm{RD}=$ children with reading disabilities; $\mathrm{TD}=$ typically developing children; K-WISCIII=Korean Wechsler Intelligence Scale for Children-III (Kwak, Park, \& Kim, 2001); RA-RCP = Test of Reading Achievement \& Reading Cognitive Processes Ability (Kim, Kim, Hwang, \& Yoo, 2014)

다. 교사 혹은 부모 보고를 통해 시각, 청각, 운동, 행동, 정서 등에 장 애가 없는 아동에게 K-WISC-III 검사를 실시하여 동작성 지능지수 가 70 이상인 아동을 선정하였다. 선정된 아동에게 RA-RCP 검사 를 실시하여 단어인지 읽기장애, 읽기유창성 읽기장애, 읽기이해 읽 기장애 중 어느 유형에도 해당하지 않는 아동을 최종 선정하였다.

실험 기간은 2014년 10월부터 2015년 4월까지 약7개월 동안이었으 며, 연구에 참여한 두 집단아동에 대한 정보는 Table 1에 나타나 있다.

읽기장애 아동과 일반 아동의 생활연령과 동작성 지능, 읽기 수 행력의 차이를 검증하기 위해 독립표본 $t$-검정을 실시한 결과, 두 집 단 간 생활연령 사이에는 유의미한 차이가 없어, 통제가 잘 이루어 진 것으로 나타났다. 반면에 K-WISC-III의 동작성 지능지수와 RA$\mathrm{RCP}$ 의 읽기 성취 지수 점수, 읽기 인지처리능력 지수 점수에서는 두 집단간 유의미한 차이가 있는 것으로 나타났다. 두 집단 간 동작 성 지능지수의 차이 $(t=4.213, p<.001)$ 는 연구의 결과 분석에 영향 을 미칠수 있으므로, 이후자료 분석에서 통제변인으로 처리하였다.

\section{연구과제}

기초 검사 도구

한국 웩슬러 아동 지능 검사(K-WISC-III)

K-WISC-III (Kwak et al., 2001)는 5세부터 15세까지 아동의 지 능을 측정하기 위한 검사로, 언어성 지능 점수와 동작성 지능 점수 를 합하여 전체 지능 점수가 산출된다. 본 연구에서는 언어성 검사 를 제외한 동작성 검사만을 실시하였으며, 검사 결과 읽기장애 아 동과 일반 아동 모두 동작성 지능지수가 70 이상인 아동이 연구 대 상으로 선정되었다.

읽기 성취 및 읽기 인지처리능력 검사 $(R A-R C P)$

읽기 성취 및 읽기 인지처리능력 검사(Test of Reading Achieve- ment \& Reading Cognitive Processes Ability, RA-RCP; Kim et al., 2014)는 초등학교 1학년부터 6학년까지 아동의 읽기 성취와 읽기 와 관련된 인지처리능력을 측정하는 표준화 검사로, 크게 읽기 성 취 검사와 읽기 인지처리능력 검사로 이루어져 있다. 읽기 성취 검 사는 3 가지 읽기영역(단어인지, 읽기유창성, 읽기이해)의 성취 검사 로 이루어져 있으며, 읽기 인지처리능력 검사는 '자모지식, 빠른 자 동 이름대기, 음운기억, 문장 따라 말하기, 듣기이해, 어휘'의 6가지 소검사로 이루어져 있다.

본 검사는 일반 아동의 읽기 능력을 종합적으로 판단할 수 있는 자료를 제공할 뿐만 아니라, 읽기장애 아동을 진단하고 읽기장애 의 하위유형(단어인지, 읽기유창성, 읽기이해) 중 어디에 속하는지 파악할 수 있도록 해준다. 해당 하위유형의 읽기 성취검사와 읽기 인지처리능력 검사 모두에서 하위 16 백분위에 속하며 지능점수가 정상 범주일 때 읽기장애라는 진단이 내려진다.

\section{실험 과제}

본 연구에서는 두 집단의 명시적 학습능력과 암묵적 학습능력 을 측정하기 위해 인공 문법 학습(AGL) 과제를 사용하였다. 연구 를 위해 Pavlidou, Williams과 Kelly (2009)에서 사용한 인공 문법 모형과 규칙 항목, 불규칙 항목 등이 차용되었으며, Pavlidou 등 (2010)에서 사용한 과제의 구성 방식을 적용하였다. 이에 따라 명시 적 학습능력을 알아보기 위한 훈련 구간에서는 '완전 자유 회상 (PFR)' 과제가 실시되었으며, 암묵적 학습능력을 알아보기 위한 검 사 구간에서는 '규칙성 판단(Grammaticality Judgment)' 과제와 '사후 인터뷰'가 실시되었다.

Appendix 1에서 보여지는 모형은 'IN', 'OUT' 표시와 화살표의 방향에 따라 도형 배열의 규칙이 정해지는 인공 문법 모형이다. 문 법 도식의 규칙을 올바로 적용하여 도형을 배열한 '규칙 항목'과, 문 법 도식의 규칙을 따르지 않고 도형을 배열한 '불규칙 항목’이 나타 나있으며, 불규칙 항목의 경우 규칙 항목의 배열 중간에 다른 도형 을 삽입하거나 원래의 도형을 다른 도형으로 바꾸어 구성하였다.

\section{명시적 학습능력 - 완전 자유 회상 (PFR) 과제}

훈련 구간에서는 완전 자유 회상 과제를 통해 명시적 학습능력 을 측정할 수 있다. 과제를 실시하기 전 아동의 앞에 4 가지 도형(삼 각형, 원, 정사각형, 직사각형)이 그려져 있는 카드를 도형별로 각각 10 장씩 준비하여 총 40 장의 도형 카드를 정렬해 놓는다. 본 과제에 서는 Pavlidou 등(2009)이 구성한 규칙 항목 22개를, 한 카드에 2개 의 규칙 항목이 들어가도록 구성하여 아동에게 총 11 개의 카드를 제시하였다. 훈련 구간에 포함된 규칙 항목 카드는 Appendix 2에 
나타나 있다. 카드 속 도형 배열은 점점 복잡해지고 길어지며, 카드 는 태블릿 PC 화면으로 1장씩 순서대로 제시되었다. Microsoft Office PowerPoint 2007 프로그램을 사용해서 11개의 카드 사이에 백 색 화면을 삽입하고, 한 카드 당 제한된 시간 15 초가 되면 자동으로 백색 화면으로 넘어가도록 설정하였다. 검사자는 각 카드를 15 초 동안 아동에게 보여준 후, 아동이 카드 속 도형 배열을 기억하여 탁 자 위에 놓인 도형을 이용해 그대로 재현하도록 지시하였다. 아동 이 첫 번째 시도에서 정확하게 카드 속 도형 배열을 재현하지 못하 면 검사자는 다시 15 초 동안 해당 카드를 보여주었다. 아동이 성공 할 때까지 이 과정을 반복하며, 11 개의 카드 재현이 끝날 때까지 같 은 형식으로 진행하였다.

\section{암묵적 학습능력 - 규칙성 판단(Grammaticality Judgment) 과제}

검사 구간에서는 규칙성 판단(Grammaticality Judgment) 과제 를 통해 암묵적 학습능력을 측정할 수 있다. 본 과제에서는 Pavlidou 등(2009)이 Knowlton과 Squire (1996)의 도식에 따라 구성한 규칙 항목(grammatical items) 16 개와 불규칙 항목(non-grammatical items) 16 개를 사용하였다. 완전 자유 회상 과제와는 달리 한 카 드에 1 가지 규칙 항목 혹은 불규칙 항목이 들어가도록 구성하여 총 32 개의 카드를 아동에게 제시하였다. 검사 구간에 포함된 규칙 항 목 카드와 불규칙 항목 카드는 Appendix 3에 제시되어 있다. 검사 자는 아동에게 완전 자유 회상 과제에서 보았던 도형 배열이 사실 은 특정한 규칙을 따른 배열이었다고 알려주었다. 이후 아동에게 새로운 도형 배열이 나타난 카드를 보여주며, 새로 보는 카드 속 배 열이 완전 자유 회상 과제에서 보았던 도형 배열과 같은 규칙을 따 랐다고 판단되면 '예’, 같은 규칙을 따르지 않았다고 판단되면 '아니 오를 답하도록 하였다. 새롭게 나타난 규칙 항목과 불규칙 항목에 대한 아동의 대답을 통해 아동이 완전 자유 회상 과제에 내재되어 있던 규칙을 암묵적으로 학습했는지의 여부를 판단할 수 있다.

\section{사후 인터뷰}

완전 자유 회상 과제와 규칙성 판단 과제가 끝난 후, 아동에게 무 엇을 근거로 도형 배열의 규칙성을 판단했는지 질문하였다. 다시 말 해, 아동이 훈련 구간을 통해 도형 배열에 내재된 규칙을 찾아냈는 지, 그것을 바탕으로 검사 구간에서 규칙성 판단을 내리는 데 사용한 특정한 규칙이나 전략이 있었는지를 물었다. 사후 인터뷰를 진행하 는 이유는 인위적인 문법 규칙에 대한 학습이 암묵적으로 이루어졌 는지를 확인하기 위함이었다. 따라서 인공 문법 모형의 규칙을 명확 히 인지하고 있음이 드러난아동은 이후 결과 분석에서 제외하였다.

\section{연구 절차}

자료 수집

자료 수집은 아동이 집중할 수 있는 환경을 제공하기 위해 외부 와 분리된 공간에서 일대일로 진행되었다. 연구에 참가할 아동을 선정하기 위해 먼저 기초 검사 도구인 K-WISC-III의 동작성 검사 를 통해 아동의 지적 능력이 정상 범주인지를 확인하였다. 또한 읽 기장애 아동을 선별하기 위해 읽기 성취 및 읽기 인지처리능력 검 사를 실시하였다. 선별 검사 결과 각 집단별로 기준에 부합하는 아 동을 연구 대상으로 선정하였다. 기초 검사 도구로써 읽기 성취 및 읽기 인지처리능력 검사에서 산출된 6 가지 소검사의 환산점수는 이후 아동의 읽기 능력 관련 변인이 명시적 학습능력 및 암묵적 학 습능력과 어떠한 상관을 보이는지 알아보기 위해 활용되었다.

기초검사에서 연구 대상으로 선정된 아동에게 실험과제인 ‘인공 문법 학습' 과제를 실시하였다. 아동의 성향과 수행력에 따라 기초 검사에 소요되는 시간은 1 시간 30 분에서 2 시간가량이었다. 실험과 제는 기초검사와 다른 날에 실시되었으며, 기초검사 이후 일주일 이 내에 이루어졌다. '인공 문법 학습' 과제는 ‘완전 자유 회상', '규칙성 판단', '사후 인터뷰' 순으로 진행되었다.

\section{검사 실시 방법}

명시적학습능력

검사를 실시하기에 앞서 아동이 다른 자극에 영향을 받지 않고 과제에만 집중할 수 있도록 테이블을 하얀 전지로 덮은 후 시작하 였다. 아동에게 15 초 동안 모니터에 나타난 카드를 보고 카드 속 도 형 배열을 기억하여 테이블 위에 똑같이 재현하라고 지시했으며, 아동이 도형 배열을 완전히 재현할 수 있을 때까지 이 과정은 11 개 의 카드 각각에 대해 반복되었다.

\section{암묵적 학습능력}

완전 자유 회상 과제가 끝난 직후, 아동이 보았던 도형의 배열이 특정한 규칙을 따른 것이었음을 언급하였다. 이어서, 같은 규칙을 따른 규칙 항목 16 개와 같은 규칙을 따르지 않은 불규칙 항목 16 개 를 태블릿 PC 화면으로 구성하여 무작위로 제시하였다. 아동으로 하여금 완전 자유 회상 과제에서 보았던 카드 속 도형과 같은 규칙 이 사용되었으면 ‘예', 같은 규칙이 사용되지 않았으면 ‘아니오' 라고 대답하도록 하였다. 제한시간은 따로 두지 않고 아동이 대답을 한 이후 다음 자극으로 넘어갔다.

\section{사후인터뷰}

완전 자유 회상 과제를 통한 아동의 학습이 암묵적인 학습이었 
는지를 확인하기 위해 사후 인터뷰를 실시하였다. 아동이 훈련 구 간에서 보았던 규칙 항목에 내재된 규칙이 무엇인지 확실히 말할 수 있다면, 검사 구간에서 진행되는 '규칙성 판단'은 암묵적 학습이 라할 수 없기 때문이다.

사후 인터뷰 결과, 규칙 항목에 내재된 규칙을 정확하게 말할 수 있는 아동은 아무도 없었다. 일반 아동 20명 중 9명과 읽기장애 아 동 20 명 중 6 명이 도형들 사이에 특정한 규칙이 존재한다는 걸 느꼈 다고 대답했지만, 단순히 “세모가 연속해서 나와요." 등 일부 규칙 을 말하는 데 그쳤고, 본 연구에서 사용한 인공 문법 모형의 전반적 인 규칙을 말할 수 있는 아동은 없었기에, 사후 인터뷰 이후 분석에 서 제외된 아동은 없었다. 이러한 결과는 아동이 완전 자유 회상 과 제에서 보았던 규칙 항목에 내재된 특정한 규칙이 명시적으로 학 습될 수 없는 규칙임을 시사하며, 규칙성 판단 과제에서 아동의 ‘예', '아니오' 대답이 암묵적인 학습을 바탕으로 이루어졌음을 의 미한다.

각 집단별로 완전 자유 회상 과제에서 제시되었던 규칙 항목들 사이에 특정한 규칙이 존재함을 인식했던 아동과 규칙의 존재를 알아차리지 못했던 아동 간 암묵적 학습능력에 유의한 차이가 있 었는지 살펴보기 위해 독립표본 t-검정을 실시한 결과, 수행력에 유 의한차이가 없는 것으로 나타났다.

\section{자료 분석}

인공 문법 학습 과제 수행력

명시적 학습능력을 평가하는 완전 자유 회상(PFR) 과제에서는 아동이 한 카드 속의 규칙 항목 2 개를 완벽하게 재현할 때까지 해 당카드를 몇 번 보아야 했는지 '시도 수를 기록하였다. 완전 자유 회상 과제가 모두 끝난 후에, 11 개의 카드 각각에 대해서 기록된 시 도 수를 모두 더한 후 총 카드수로 나누었고, 이렇게 산출된 '평균 시도 수'가 곧 아동의 완전 자유 회상 과제 점수로 기록되었다. 평균 시도 수가 높다는 것은 아동이 과제를 수행하기 위해 카드를 빈번 히 보아야 했음을 나타내며, 이는 곧 아동의 명시적 학습능력이 낮 았음을 의미한다. 반대로, 평균 시도 수가 낮다는 것은 곧 아동의 명시적 학습능력이 높았음을 의미한다.

암묵적 학습능력을 평가하는 규칙성 판단(Grammaticality Judgment) 과제에서는 아동이 규칙 항목에 대해 ‘예', 불규칙 항목에 대 해 '아니오’라고 답했을 경우 정반응으로 기록하였다. 반대로 규칙 항목에 대해 ‘아니오', 불규칙 항목에 대해 ‘예’라고 답했을 경우에 는 오반응으로 기록하였다. 전체 32 개 항목에 대해 정반응시 1 점, 오반응시 0 점을 부여하였고, 따라서 총점은 0 점부터 32 점 사이의 값을 가지는 것으로 기록되었다.
읽기 성취 및 읽기 인지처리 능력 검사 중 6 가지 소검사의 수행력

‘자모지식', ‘빠른 자동 이름대기', ‘음운기억', '문장 따라 말하기', '듣기이해' '어휘’의 6가지 소검사 중 일부는 학년에 따라 원점수의 총점이 다르게 산출된다. 게다가, 같은 원점수라도 학년에 따라 그 수행력은 다른 것으로 판단된다. 따라서 본 연구에서는 각 소검사 의 학년집단별 원점수가 평균 10 , 표준편차 3 의 분포로 변환된 환 산점수를 이용하였다. 환산점수는 검사를 모두 실시한 후, 원점수 를 온라인 채점프로그램에 입력하면 자동으로 산출되었다.

\section{자료의 통계적 처리}

연구문제에 대한 자료의 분석은 SPSS ver. 18 을 사용하였으며, 자 료의 통계적 처리는 다음과 같다. 첫째, 읽기장애 아동과 일반 아동 의 명시적인 학습능력에 유의한 차이가 있는지 알아보기 위해, 완 전 자유 회상 과제의 수행력에 대해 동작성 지능을 통제변인으로 처리하는 공분산분석(ANCOVA)을 실시하였다. 둘째, 항목의 유 형(규칙성, 불규칙성)에 따라 두 집단 아동의 암묵적 학습능력에 유의한 차이가 있는지 살펴보기 위해, 규칙성 판단 과제의 수행력 에 대해 동작성 지능을 통제변인으로 설정한 후 이원혼합 공분산 분석(two-way mixed ANCOVA)를 실시하였다. 셋째, 각 집단별로 명시적 학습능력과 암묵적 학습능력 사이에 유의한 상관관계가 있는지, 또한 각 집단별로 읽기 능력 관련 변인과 두 학습능력은 어 떠한 상관을 보이는지 알아보기 위해 Pearson의 적률상관계수를 측정하였다.

\section{연구 결과}

\section{읽기장애 아동과 일반 아동의 명시적 학습능력}

읽기장애 아동 집단과 일반 아동 집단 간 명시적 학습능력에 유 의한 차이가 있는지 살펴보기 위해, 인공 문법 학습 과제의 '완전 자유 회상(PFR)' 과제를 통하여 수행능력을 비교하였다. '완전 자 유 회상' 과제에서 기록된 '평균 시도 수가 적을수록 명시적 학습 능력이 높은 것으로, '평균 시도 수'가 많을수록 명시적 학습능력이 낮은 것으로 측정되었다. 집단 간 명시적 학습능력(시도 수)에 대한 기술통계는 Table 2에 제시하였다.

공분산분석 결과, 완전 자유 회상 과제를 통해 살펴 본 집단 간 명시적 학습능력의 차이는 통계적으로 유의하였다 $\left(F_{(1,37)}=9.502\right.$, $p<.01)$. 즉 읽기장애 아동은 일반 아동에 비하여 카드 속 도형배열 을 완전히 재현하도록 하기 위해 유의한 수준으로 더 많은 시도를 했다(Figure 1). 
Table 2. Descriptive statistics on explicit learning ability (mean number of trials) between two groups

\begin{tabular}{lcc}
\hline & $\mathrm{RD}(\mathrm{N}=20)$ & $\mathrm{TD}(\mathrm{N}=20)$ \\
\hline Explicit learning ability & $2.546^{\mathrm{a}}(.097)$ & $2.084^{\mathrm{a}}(.097)$ \\
\hline
\end{tabular}

Values are presented as mean (SE).

$\mathrm{RD}=$ children with reading disabilities; $\mathrm{TD}=$ typically developing children.

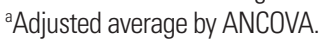

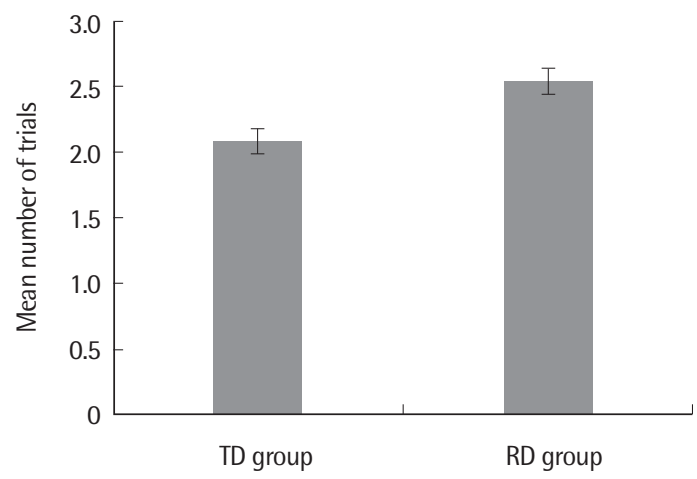

Figure 1. Explicit learning ability (mean number of trials) between two groups. $\mathrm{RD}=$ children with reading disabilities; $\mathrm{TD}=$ typically developing children.

Table 3. Implicit learning achievement in both groups

\begin{tabular}{lcccc}
\hline & Average correct answer (SD) & $t$ & $d f$ & $p$-value \\
\hline $\mathrm{TD}(\mathrm{N}=20)$ & $19.80(2.764)$ & 6.147 & 19 & $.000^{* * *}$ \\
$\mathrm{RD}(\mathrm{N}=20)$ & $17.65(2.739)$ & 2.694 & 19 & $.014^{*}$ \\
\hline
\end{tabular}

$\mathrm{RD}=$ children with reading disabilities; $\mathrm{TD}=$ typically developing children . ${ }^{*} p<.05,{ }^{* * *} p<.001$.

\section{읽기장애 아동과 일반 아동의 암묵적 학습능력}

인공 문법 학습 과제의 '규칙성 판단(Grammaticality Judgment)' 과제를 통하여 각 집단별로 암묵적 학습이 우연수준을 넘어서 통 계적으로 유의한 수준으로 이루어졌는지를 측정하기 위해 집단별 로 일표본 $t$-검정(one-sample $t$-test)을 실시하였으며, 결과는 Table 3 에 제시하였다. 분석에는 전체 32개 항목에 대해 우연 수준인 16 개 항목, 즉 $50 \%$ 의 정반응에 미치지 못하였던 아동들(일반 아동 1 명, 읽기장애 아동 4 명)의 자료도 포함하였다. $t$-검정 결과, 일반아 동의 암묵적 학습 $(t=6.147, p<0.001)$ 과 읽기장애 아동의 암묵적 학습 $(t=2.657, p<.05)$ 이 모두 통계적으로 유의한 수준으로 나타 났다. 구체적으로 살펴보면, 일반 아동은 32 개 항목에 대해 평균 19.80 개의 항목에 대해 정반응하였고, 읽기장애 아동은 평균 17.65 개의 항목에 대해 정반응하였다. 이러한 결과는 두 집단 아동이 전 체 32 개 항목의 우연 수준인 16 개 항목에 대해 통계적으로 유의한 차이로 정반응하였음을 의미한다.

두 집단 간 규칙성 판단 과제의 항목 유형(규칙성, 불규칙성)에
Table 4. Descriptive statistics on implicit learning ability (total score of correct answers) according to type of items (grammaticality or not) between two groups

\begin{tabular}{llr}
\hline & $\mathrm{RD}(\mathrm{N}=20)$ & $\mathrm{TD}(\mathrm{N}=20)$ \\
\hline Implicit learning ability & & \\
Grammatical items & $8.773^{\mathrm{a}}(.631)$ & $10.727^{\mathrm{a}}(.631)$ \\
Non-grammatical items & $8.782^{\mathrm{a}}(.674)$ & $9.168^{\mathrm{a}}(.674)$ \\
\hline
\end{tabular}

$\mathrm{RD}=$ children with reading disabilities; $\mathrm{TD}=$ typically developing children .

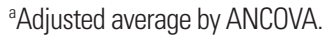

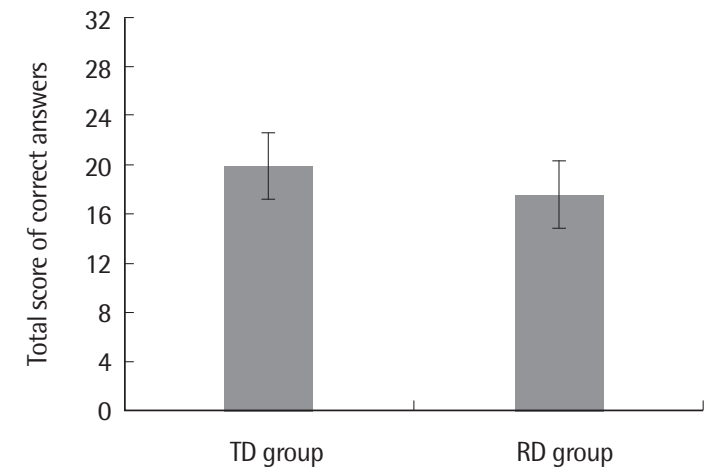

Figure 2. Implicit learning ability (total score of correct answers) between two groups. $\mathrm{RD}=$ children with reading disabilities; $\mathrm{TD}=$ typically developing children.

따른 암묵적 학습능력의 차이가 통계적으로 유의한 것인지 살펴보 기 위해 동작성 지능을 통제변인으로 처리한 후 이원혼합 공분산 분석(two-way mixed ANCOVA)을 실시하였으며, 암묵적 학습능 력에 대한 기술통계는 Table 4에 제시하였다.

이원혼합 공분산분석 결과, 규칙성 판단 과제를 통해 살펴본 집 단 간 암묵적 학습능력의 차이는 통계적으로 유의하였다 $\left(F_{(1,37)}=\right.$ $4.810, p<.05)$. 즉 규칙성 판단 과제의 수행력을 알아보기 위한 '정 반응한 항목 수'에서 읽기장애 아동은 일반 아동에 비하여 유의한 수준으로 낮은 수행력을 보였다(Figure 2).

한편, 항목 유형에 따른 암묵적 학습능력에는 유의한 차이가 나 타나지 않았으며 $\left(F_{(1,37)}=.199, p>.05\right)$, 집단과 항목유형에 따른 상 호작용 효과 또한 유의하지 않았다 $\left(F_{(1,37)}=.841, p>.05\right)$. 이는 규칙 항목과 불규칙 항목의 정반응 수에 유의한 차이가 없었음을 의미 한다. 하지만 읽기장애 아동의 경우 규칙 항목과 불규칙 항목의 정 반응 수에 거의 차이가 없었던 반면, 일반 아동의 경우 통계적으로 유의한 수준은 아닐지라도 규칙 항목에서 불규칙 항목보다 더 많 이 정반응하는 모습을 보였다.

\section{각 집단별 읽기능력 관련 변인과 명시적 학습능력 및 암묵적 학습능력 간의 상관관계}

일반 아동 집단과 읽기장애 아동 집단에서 읽기능력 관련 변인 
Table 5. Pearson product-moment correlation coefficients between variables related to reading ability and explicit/implicit learning ability in both groups

\begin{tabular}{|c|c|c|c|c|c|c|c|}
\hline & \multicolumn{6}{|c|}{ Cognitive processing abilities related to reading } & \multirow{2}{*}{$\begin{array}{l}\text { Implicit learning } \\
\text { ability }\end{array}$} \\
\hline & $\begin{array}{c}\text { Alphabet } \\
\text { knowledge }\end{array}$ & $\begin{array}{c}\text { Rapid } \\
\text { naming }\end{array}$ & $\begin{array}{c}\text { Phonological } \\
\text { memory }\end{array}$ & $\begin{array}{c}\text { Syntax } \\
\text { processing }\end{array}$ & $\begin{array}{c}\text { Aural } \\
\text { understanding }\end{array}$ & Vocabulary & \\
\hline \multicolumn{8}{|c|}{ Explicit learning ability ( $\mathrm{N}$ of trials) } \\
\hline $\mathrm{TD}(\mathrm{N}=20)$ & $-.557^{*}$ & -.212 & $-.655^{* *}$ & $-.492^{*}$ & -.334 & $-.703^{* *}$ & -.394 \\
\hline $\mathrm{RD}(\mathrm{N}=20)$ & $-.499 *$ & .157 & -.189 & $-.487^{*}$ & -.016 & .102 & -.209 \\
\hline \multicolumn{8}{|c|}{ Implicit learning ability (correct answer) } \\
\hline $\mathrm{TD}(\mathrm{n}=20)$ & .234 & -.251 & .423 & $.614^{* *}$ & .250 & .383 & 1 \\
\hline $\mathrm{RD}(\mathrm{n}=20)$ & .403 & -.217 & .382 & $.448^{*}$ & .147 & $.485^{*}$ & 1 \\
\hline
\end{tabular}

$\mathrm{RD}=$ children with reading disabilities; $\mathrm{TD}=$ typically developing children . ${ }^{*} p<.05,{ }^{* *} p<.01$.

(자모지식, 빠른 자동 이름대기, 음운기억, 통사처리, 듣기이해, 어 휘)과 명시적 학습능력 및 암묵적 학습능력 간에 통계적으로 유의 한 상관관계가 있는지 살펴보기 위해 Pearson의 적률상관분석을 실시하였고, 결과는 Table 5에 제시하였다.

분석 결과, 일반 아동의 명시적 학습능력의 경우 자모지식 $(r=$ $-.557, p<.05)$, 음운기억 $(r=-.655, p<.01)$, 통사처리 $(r=-.492, p<.05)$, 어휘 $(r=-.703, p<.01)$ 에서 유의한 상관관계가 나타났으며, 암묵적 학습능력의 경우 통사처리 $(r=.614, p<.01)$ 에서 유의한 상관관계 가 나타났다. 반면, 명시적 학습능력과 암묵적 학습능력 사이에는 통계적으로 유의한 상관관계가 나타나지 않았다.

읽기장애 아동의 명시적 학습능력의 경우 자모지식 $(r=-.499$, $p<.05)$, 통사처리 $(r=-.487, p<.05)$ 에서 유의한 상관관계가 나타났 으며, 암묵적 학습능력의 경우 통사처리 $(r=.448, p<.05)$, 어휘 $(r=$ $.485, p<.05)$ 에서 유의한 상관관계가 나타났다. 반면, 명시적 학습 능력과 암묵적 학습능력 사이에는 통계적으로 유의한 상관관계가 나타나지 않았다.

\section{논의 및 결론}

\section{집단 간 명시적 학습능력 비교}

읽기장애 아동과 일반 아동의 명시적 학습능력에 차이가 있는 지 살펴본 결과, 읽기장애 아동의 명시적 학습능력이 일반 아동의 명시적 학습능력에 비해 유의하게 낮은 것으로 나타났다. 읽기장애 아동은 검사자가 제시하는 카드를 완전하게 재현하기 위해 한 카드 당 일반 아동보다 유의하게 더 시도하는 모습을 보였다. 이는 읽기 장애 아동과 일반 아동의 명시적 학습능력에 유의한 차이가 없다 고 주장한 선행연구와 일치하지 않는 결과이다(Jiménez-Fernández et al., 2011; Pavlidou et al., 2010; Vicari et al., 2003).

그동안 인공 문법 학습(AGL) 과제를 실시한 선행연구를 살펴보 면 사용한 인공 문법 모형은 서로 다를지라도, 명시적 학습능력을
측정하기 위해 완전 자유 회상(PFR) 과제를 활용한다는 공통점을 발견할 수 있다. 본래 기억력을 측정하는 보통의 검사는 규칙과는 상관이 없는 학습 자극을 무작위로 제시한다. 하지만 완전 자유 회 상 과제는 자극 자체가 일련의 인위적인 규칙성을 토대로 구성되었 다는 점에서 차이를 보인다. 인위적인 규칙성을 기반으로 하는 학 습임에도 불구하고, 완전 자유 회상을 암묵적 학습 과제가 아닌 명 시적 학습 과제로 분류하는 이유는 대상 아동들이 자극을 그대로 재현하는 과정에서 의식적으로 그리고 의도적으로 자극을 학습하 려 했기 때문이다. 읽기장애 아동의 명시적 학습능력이 손상되지 않았음을 밝혔던 선행연구들은 읽기장애 아동의 기억 용량이 부 족하다는 사실(Swanson \& Jerman, 2007)에도 불구하고 이러한 구 조적인 속성, 즉 학습 자극에 내재된 근본적인 규칙성이 아동의 명 시적 학습에 도움을 주었을 가능성을 제시하고 있다(Pavlidou et al., 2010). 하지만, 본 연구에서는 선행 연구에서 주장하는 것과 반 대로 자극에 내재된 규칙성이 읽기장애 아동의 명시적 학습을 도 울 만큼 영향을 미치지 못했음을 나타낸다. 따라서, 학습에 내재된 규칙성이 읽기장애 아동의 기억 용량 결함을 상쇄할 정도로 명시적 인 학습에 긍정적으로 작용하지는 않는다는 결론을 내릴 수 있다.

과제의 구조적인 속성이 읽기장애 아동의 학습에 도움을 주지 못한 것과 더불어, 과제를 수행하기 위해 각 집단의 아동이 사용한 전략에서도 차이가 있었던 것으로 생각해 볼 수 있다. 연구에 참여 한 일반 아동 중 많은 수가 카드 속의 도형 배열을 그대로 재현하는 과정에서 2 개의 도형배열을 동시에 구성하는 전략을 사용하였다. 하지만 읽기장애 아동의 경우 2 개의 도형배열을 함께 고려하지 못 하고, 각각 따로 구성하는 전략을 주로 사용하였다. 예를 들어 한 카드 안에 ‘원-직사각형-정사각형-원-삼각형’ 배열과 ‘삼각형-원-직 사각형-정사각형-원-직사각형’ 배열이 함께 제시되었던 경우, 일반 아동은 두 도형 배열에서 '원-직사각형-정사각형-원'이 같다는 점 을 인식하고 두 개의 도형배열을 동시에 구성하는 모습을 보였다. 하지만 읽기장애 아동 대부분은 도형배열 하나를 먼저 완성한 후, 
이어서 두 번째 도형배열을 구성하는 등 두 개의 도형배열을 분리 하여 생각하는 모습을 보이며 과제를 효율적으로 수행하기 위한 적절한 전략의 부재를 드러냈다.

\section{집단 간 암묵적 학습능력 비교}

집단에 따라서 암묵적 학습능력에 차이가 있는지 살펴본 결과, 읽기장애 아동의 암묵적 학습능력이 일반 아동의 암묵적 학습능 력에 비해 유의하게 낮은 것으로 나타났다. 읽기장애 아동은 규칙 성 판단 과제에서 일반 아동에 비해 유의한 수준으로 정반응 수준 이 떨어졌으며, 이는 지금까지 인공 문법 학습 과제를 사용하여 읽 기장애 아동의 암묵적 학습능력을 측정한 선행연구들과 일치하는 결과이다(Pavlidou et al., 2009, 2010).

다만, Pavlidou 등(2010)에서 읽기장애 아동의 암묵적 학습능력 이 우연 수준을 벗어나지 않았던 것과 본 연구의 결과를 비교하여 살펴볼 필요는 있다. 본 연구에서는 집단 간 수행력의 차이는 발생 했지만, 두 집단 아동 모두 우연 수준을 유의하게 넘어서는 암묵적 학습능력을 보였다. 다시 말해, 읽기장애 아동은 일반 아동에 비해 학습의 효과가 저하되기는 하지만, 분명히 암묵적 학습능력을 가지 고 있으며, 명시적인 학습을 통해 습득된 지식으로 내재된 규칙성 을 추론해낼 수 있다. 이러한 연구 결과는 읽기장애 아동을 중재할 때에 암묵적인 학습 과정으로 읽기의 복잡한 규칙에 대한 학습을 유도하는 것이 아동의 학습에 적게나마 긍정적인 영향을 끼친다는 점을 시사한다.

항목유형(규칙성, 불규칙성)에 따라 암묵적 학습능력에 차이가 있는지 살펴본 결과, 통계적으로 유의한 차이가 없는 것으로 나타 났다. 즉, 두 집단 아동은 규칙 항목에 대한 수행력과 불규칙 항목 에 대한 수행력에서 차이를 보이지 않았다. 이러한 결과는 항목유 형에 따른 주효과가 유의함을 확인했던 선행연구의 결과(Pavlidou et al., 2009, 2010)와 일치하지 않는 것이다. 항목유형이 암묵적 학 습능력에 별다른 영향을 미치지 않았다는 점은 언어를 습득하는 전반적인 과정과 연관시켜 생각해볼 수 있다. 문자소와 음소의 대 응과 관련한 언어 학습의 초기부터 조사와 피동문 등 점차 복잡한 문법 규칙을 배우는 학령기까지 언어는 규칙성에 대한 학습을 기 반으로 자동화에 이르는 과정이다. 주목할 점은 언어를 습득할 때 우리는 다양한 규칙을 배우지만, 그에 비례하는 만큼 불규칙성을 배우지는 않는다는 점이다. 예를 들어, 우리는 명시적으로 주격조 사에 ‘이'와 '가'가 사용된다는 규칙을 배운다. 따라서 '철수가 사과 를 먹는다라는 문장이 문법적으로 옳은 문장이라는 판단을 내릴 수 있다. 반면, 주격조사 자리에 올 수 없는 단어에 대한 학습, 즉 주 격조사에 관한 불규칙성을 학습하지 않았는데도 불구하고, 우리
는 '철수에서 사과를 먹는다'라는 문장의 문법적 오류를 판단할 수 있다. 이와 같이 규칙성에 대한 학습은 동시에 불규칙성에 대한 학 습까지 가능하게 하며, 본 연구에서도 완전 자유 회상 과제에서 학 습했던 규칙 항목에 내재된 규칙성이 불규칙 항목에 대한 학습의 성취를 도왔음을 추론할 수 있다.

비록 항목 유형에서 유의한 차이는 나타나지 않았지만, 집단 간 암묵적 학습능력의 유의미한 차이는 규칙 항목에 대한 수행력 차 이에서 기인하는 것으로 예상한다. 불규칙 항목에서 읽기장애 아 동은 8.782개, 일반 아동은 9.168 개로 정반응 수의 차이가 미미하지 만, 규칙 항목에서는 읽기장애 아동 8.773개, 일반 아동 10.727 개로 두 집단 아동의 정반응 수의 차이가 거의 2 개로 나타나고 있다. 이 러한 결과를 통해, 읽기장애 아동이 일반 아동보다 규칙 항목에 대 한 민감도가 손상된 것으로 결론을 내릴 수 있으며, 반면 불규칙 항 목, 즉 문법상의 오류에 대해서는 두 아동이 비슷한 수준으로 인식 한다는 것을 알수 있다.

읽기장애 아동의 명시적 학습능력 및 암묵적 학습능력을 살펴 본 본 연구의 결과를 선행연구의 결과와 비교하여 정리하면 다음 과 같다. 첫째, 읽기장애 아동의 명시적 학습능력은 일반 아동보다 유의하게 낮으며 이는 선행연구의 결과와 일치하지 않는다. 둘째, 읽기장애 아동의 암묵적 학습능력은 일반 아동보다 유의하게 낮 아 선행연구의 결과와 일치하지만, 읽기장애 아동도 일반 아동처럼 우연 수준을 넘어서는 암묵적 학습능력을 보였다는 점에서 차이가 있다. 다만 이러한 연구 결과의 차이를 해석할 때, 선행연구와의 대 상군의 차이가 영향을 미쳤을 가능성을 배제할 수 없다. Pavlidou 등(2010)은 '발달성 난독증(developmental dyslexia)' 군을 대상으 로 연구를 수행했지만, 본 연구는 '단어인지', '읽기유창성' ‘읽기이 해' 세 영역 중 한 영역 이상에 장애가 있는 아동을 모두 포함해서 연구를 진행하였다. 따라서 앞으로의 후속 연구에서는 발달성 난 독증 아동만을 대상으로 명시적 학습능력 및 암묵적 학습능력을 살펴보고 그 결과를 Pavlidou 등(2010) 및 본 연구의 결과와 비교하 는 것이 의미있을 것으로 생각된다.

\section{집단 별 읽기능력 관련 변인과 명시적 학습능력 및 암묵적 학습능력 간의 상관관계}

일반 아동의 명시적 학습능력은 '자모지식, 음운기억, 통사처리, 어휘'와, 암묵적 학습능력은 ‘통사처리’와 유의한 상관이 있는 것으 로 나타났다. 반면 읽기장애 아동의 명시적 학습능력은 '자모지식, 통사처리'와, 암묵적 학습능력은 '통사처리, 어휘’와 통계적으로 유 의한 상관관계가 나타났다.

두 집단 아동 모두 명시적 학습능력과 자모지식 사이에 유의한 
상관관계를 보인 것은 예상할 수 있는 결과이다. 자모지식, 즉 자모 의 이름과 소리를 정확하게 인지하는 능력은 명시적인 학습을 통 해 습득된다. 특히, 자소와 음소 사이에 일대일 대응을 원칙으로 하 는 한국어의 특성을 고려하면, 자소-음소 대응에 대한 지식이 명시 적인 학습과 밀접하게 연관되어 있음을 추측할 수 있다.

본 연구 결과에서 가장 주목할 점은 두 집단 모두 통사처리 능력 이 명시적 학습능력 및 암묵적 학습능력과 유의한 상관관계를 가 지는 것으로 나타났다는 점이다. 이는 Yim과 Windsor (2010), 그리 고 Conway 등(2010)의 연구결과와 어느 정도 일치하는 것으로 보 인다. 본 연구에서 통사처리 능력을 측정하기 위해 실시한 '문장 따 라 말하기' 과제는 적절한 수행을 위해 구문구조와 문법에 관한 지 식이 선행되어야 하는 과제이다. 즉, 통사처리 능력이란 장기간에 걸쳐 습득되는 언어능력이라 할 수 있으며, 선행연구에서는 복잡한 규칙성을 토대로 한 언어능력이 암묵적 학습능력과 깊은 상관을 가진다고 밝혔으므로, 암묵적 학습능력과 통사처리 능력이 밀접하 게 연결되어 있음을 이해할 수 있다. 한편 명시적 학습능력과 통사 처리 능력의 유의한 상관관계는 본 연구의 과제 특성을 고려해볼 수 있을 것이다. 본 연구에서 명시적 학습능력의 측정은 제시되는 학습 자극을 기억하여 그대로 재현하는 과정에서 이루어졌고, 통 사처리 능력의 측정 또한 검사자가 불러주는 문장을 아동이 듣고 그대로 기억하여 말하는 과정을 통해 이루어졌기 때문이다. 두 과 제가 모두 아동의 단기기억을 요구한다는 점으로 미루어볼 때, 명 시적 학습능력과 통사처리 능력의 유의한 상관이 설명될 수 있다. 따라서 통사처리는 읽기장애 유무와 상관없이 명시적 학습능력 및 암묵적 학습능력과 상관이 높다는 결론을 내릴 수 있다.

상관관계 분석에서 집단 간 차이를 보였던 읽기 관련 변인은 음 운기억과 어휘였다. 음운기억의 경우 일반 아동 집단에서만 명시적 학습능력과 유의한 상관관계가 나타났고, 읽기장애 아동 집단에 서는 두 학습능력과 아무런 상관이 나타나지 않았다. 본 연구에서 명시적 학습능력이 규칙 항목을 그대로 재현하는 완전 자유 회상 과제에서의 수행력으로 측정되었음을 고려할 때, 단기기억과 작업 기억을 수반하는 음운기억이 명시적 학습능력과 밀접한 상관이 있 다는 것은 자연스러운 결과이다. 하지만 유의한 상관관계를 보이지 않은 읽기장애 아동의 경우 두 과제의 자극이 제시되었던 방식에 서 차이가 있었던 점을 고려해보아야 한다. 완전 자유 회상 과제는 시각적 자극이 제시된 반면, 음운기억 과제는 청각적 자극이 제시 되었다. 일반아동의 경우 자극의 양식 차이가 기억 용량을 활성화 시키는 과정에서 별다른 영향을 미치지 않았지만, 읽기장애 아동 의 경우 시각과 청각이라는 감각 양식의 차이가 기억 용량을 요구 하는 각 과제에서 수행력에 영향을 미쳤을 수도 있다.
본 연구에서 일반 아동은 명시적 학습능력에서만 어휘와 유의 한 상관이 있었으며, 반대로 읽기장애 아동은 암묵적 학습능력에 서만 어휘와 유의한 상관을 나타냈다. 명시적 학습능력과 어휘 사 이에 유의한 상관이 있음을 밝혔던 선행연구의 결과를 고려할 때 (Kidd, 2012; Ullman, 2004), 읽기장애 아동이 어휘에 대해 보여주 는 결과는 선행연구와 상반된다는 점을 확인할 수 있다. 이러한 연 구 결과는 어휘와 읽기 이해 능력 사이에 강한 상관관계가 있음을 밝혔던 선행연구의 결과(Cunningham \& Stanovich, 1997; Ouellette \& Beers, 2010)를 토대로 해석해 볼 수 있다. 본 연구에서 일반 아동의 ‘이해인지처리' 능력은 명시적 학습능력 및 암묵적 학습능 력 모두와 상관관계를 보였다. 반면, 읽기장애 아동의 '이해인지처 리' 능력은 암묵적 학습능력에만 상관이 있음을 나타냈다. 따라서 일반 아동의 경우 ‘어휘-읽기 이해-명시적 및 암묵적 학습능력' 사 이의 관계를, 읽기 장애 아동의 경우 '어휘-읽기 이해-암묵적 학습 능력'의 관계를 유추해볼 수 있다. 하지만 일반 아동의 암묵적 학습 능력에서 어휘와 상관이 나타나지 않은 이유는 이러한 추론으로 설명되지 않기에, 어휘와의 관련성을 중점으로 설명해 줄 수 있는 연구가 수행될 필요가 있다.

연구 결과에서 나타난 두 집단 아동의 읽기 능력 관련 변인과 명 시적 학습능력 및 암묵적 학습능력의 상관관계는 읽기의 하위영역 과 관련지어 살펴볼 수 있다. 본 연구에서 살펴본 읽기 능력 관련 변 인은 RA-RCP의 하위검사로, '단어인지' 영역은 '자모지식, 빠른 자 동 이름대기, 음운기억, 어휘' '읽기유창성' 영역은 ‘빠른 자동 이름 대기, 어휘' '읽기이해' 영역은 '문장 따라 말하기(통사처리), 듣기이 해, 어휘'로 각각 구성되어 있다. 세 하위영역별로 명시적 학습능력 및 암묵적 학습능력과의 상관관계를 살펴본 결과는 Appendix 4에 제시하였다. 분석 결과, 일반 아동의 경우 명시적 학습능력은 '단어 인지처리', '유창성인지처리' '이해인지처리' 세 영역 모두와 유의한 상관이 나타났으며, 암묵적 학습능력은 ‘이해인지처리' 영역에서 유의한 상관을 보였다. 읽기장애 아동의 경우 명시적 학습능력은 각 유형별 인지처리능력과 아무런 상관을 보이지 않았고, 암묵적 학습능력은 ‘단어인지처리’와 ‘이해인지처리' 영역에서 유의한 상 관이 나타났다. 이러한 결과를 종합하면 일반 아동의 경우 읽기 관 련 인지처리능력이 명시적 학습능력과 높은 상관을 보이며, 읽기장 애 아동의 경우 읽기 관련 인지처리능력이 암묵적 학습능력과 높 은 상관을 보인다는 결론을 얻을 수 있다. 또한 두 집단 아동 모두 '이해인지처리' 영역에서 암묵적 학습능력과 유의한 상관이 나타 났다는 점을 통해 읽기이해와 암묵적 학습능력 사이의 높은 상관 은 장애유무를 떠나 공통된 특성임을 알 수 있다.

한편, 읽기장애 아동과 일반 아동 모두 명시적 학습능력과 암묵 
적 학습능력 사이에는 유의한 상관관계가 나타나지 않았다. 즉, 명 시적인 학습 과제에서의 수행력과 암묵적인 학습 과제에서의 수행 력은 서로 영향을 미치지 않았음을 의미하며, 이는 두 학습능력 간 연관성이 있을 것으로 예상했던 선행연구(Dienes, Broadbent, \& Berry, 1991)와도 일치하지 않는 결과이다. 하지만, 명시적 학습능 력과 암묵적 학습능력이 공통된 기반을 공유하지 않으며 서로 독 립적인 토대에서 학습이 이루어진다는 결론을 성급하게 내릴 수는 없다. 명시적 학습능력과 암묵적 학습능력을 측정하기 위한 과제 는 본 연구와 다르게 구성될 수 있으며, 과제의 구조적인 속성 등에 따라 얼마든지 영향을 받을 수 있을 것으로 여겨지기 때문이다. 두 학습능력 사이의 상관관계에 대해서는 앞으로 후속 연구를 통해 연구 결과가 더욱 축적되어야할 것으로 보인다.

\section{REFERENCES}

Arciuli, J., \& Simpson, I. C. (2012). Statistical learning is related to reading ability in children and adults. Cognitive Science, 36, 286-304.

Baik, J., Lee, S. Y., Kim, Y., \& Lee, S. J. (2012). Working memory and Grammaticality Judgment Test. Korean Journal of Applied Linguistics, 28, 31-58.

Conway, C. M., Bauernschmidt, A., Huang, S. S., \& Pisoni, D. B. (2010). Implicit statistical learning in language processing: word predictability is the key. Cognition, 114, 356-371.

Cunningham, A. E., \& Stanovich, K. E. (1997). Early reading acquisition and its relation to reading experience and ability 10 years later. Developmental Psychology, 33, 934-945.

Dienes, Z., Broadbent, D., \& Berry, D. C. (1991). Implicit and explicit knowledge bases in artificial grammar learning. Journal of Experimental Psychology: Learning, Memory, and Cognition, 17, 875-887.

Evans, J. L., Saffran, J. R., \& Robe-Torres, K. (2009). Statistical learning in children with specific language impairment. Journal of Speech, Language, and Hearing Research, 52, 321-335.

Gombert, J. E. (2003). Implicit and explicit learning to read: implication as for subtypes of dyslexia. Current Psychology Letters: Behaviour, Brain \& Cognition, 10, 1-8.

Harm, M. W., \& Seidenberg, M. S. (2004). Computing the meanings of words in reading: cooperative division of labor between visual and phonological processes. Psychological Review, 111, 662-720.

Howard, J. H., Howard, D. V., Japikse, K. C., \& Eden, G. F. (2006). Dyslexics are impaired on implicit higher-order sequence learning, but not on implicit spatial context learning. Neuropsychologia, 44, 1131-1144.
Jiménez-Fernández, G., Vaquero, J. M., Jiménez, L., \& Defior, S. (2011). Dyslexic children show deficits in implicit sequence learning, but not in explicit sequence learning or contextual cueing. Annals of Dyslexia, 61, 85110.

Kelly, S. W., Griffiths, S., \& Frith, U. (2002). Evidence for implicit sequence learning in dyslexia. Dyslexia, 8, 43-52.

Kidd, E. (2012). Implicit statistical learning is directly associated with the acquisition of syntax. Developmental Psychology, 48, 171-184.

Kim, A. H. (2013). Prediction of reading comprehension of elementary students: a 20-month longitudinal study. Communication Sciences \& Disorders, $18,258-268$.

Kim, A. H., Kim U. J., Hwang, M., \& Yoo, H. S. (2014). Test of reading achievement and reading cognitive processes ability. Seoul: Hakjisa.

Kim, Y. T. (2014). Assessment and Treatment of Language Disorders in Children (2nd ed.). Seoul: Hakjisa.

Knowlton, B. J., \& Squire, L. R. (1996). Artificial grammar learning depends on implicit acquisition of both abstract and exemplar-specific information. Journal of Experimental Psychology: Learning, Memory, and Cognition, 22, 169-181.

Kwak, K. C., Park, H. W., \& Kim, C. T. (2001). Korean Wechsler Intelligence Scale for Children-III (K-WISC-III). Seoul: Seoul Special Education Publishing.

Nicolson, R. I., \& Fawcett, A. J. (1999). Developmental dyslexia: the role of the cerebellum. In I. Lundberg et al. (Eds.), Dyslexia: advances in theory and practice (pp. 173-196). Dordrecht: Kluwer Academic Publishers.

Ouellette, G., \& Beers, A. (2010). A not-so-simple view of reading: how oral vocabulary and visual-word recognition complicate the story. Reading and Writing, 23, 189-208.

Pavlidou, E. V., \& Williams, J. M. (2014). Implicit learning and reading: Insights from typical children and children with developmental dyslexia using the artificial grammar learning (AGL) paradigm. Research in Developmental Disabilities, 35, 1457-1472.

Pavlidou, E. V., Kelly, L. M., \& Williams, J. M. (2010). Do children with developmental dyslexia have impairments in implicit learning? Dyslexia, 16, 143-161.

Pavlidou, E. V., Williams, J. M., \& Kelly, L. M. (2009). Artificial grammar learning in primary school children with and without developmental dyslexia. Annals of Dyslexia, 59, 55-77.

Roodenrys, S., \& Dunn, N. (2008). Unimpaired implicit learning in children with developmental dyslexia. Dyslexia, 14, 1-15. 
Rüsseler, J., Gerth, I., \& Münte, T. F. (2006). Implicit learning is intact in adult developmental dyslexic readers: Evidence from the serial reaction time task and artificial grammar learning. Journal of Clinical and Experimental Neuropsychology, 28, 808-827.

Schacter, D. L. (1992). Implicit knowledge: new perspectives on unconscious processes. Proceedings of the National Academy of Sciences, 89, 11113-11117.

Sperling, A. J., Lu, Z. L., \& Manis, F. R. (2004). Slower implicit categorical learning in adult poor readers. Annals of Dyslexia, 54, 281-303.

Stein, J. (2001). The magnocellular theory of developmental dyslexia. Dyslexia, 7, 12-36.

Swanson, H. L., \& Jerman, O. (2007). The influence of working memory on reading growth in subgroups of children with reading disabilities. Journal of Experimental Child Psychology, 96, 249-283.

Ullman, M. T. (2004). Contributions of memory circuits to language: the declarative/procedural model. Cognition, 92, 231-270.

Vicari, S., Marotta, L., Menghini, D., Molinari, M., \& Petrosini, L. (2003). Implicit learning deficit in children with developmental dyslexia. Neuropsychologia, 41, 108-114.

Yim, D., \& Windsor, J. (2010). The roles of nonlinguistic statistical learning and memory in language skill. Korean Journal of Communication Disorders, 15, 381-396. 


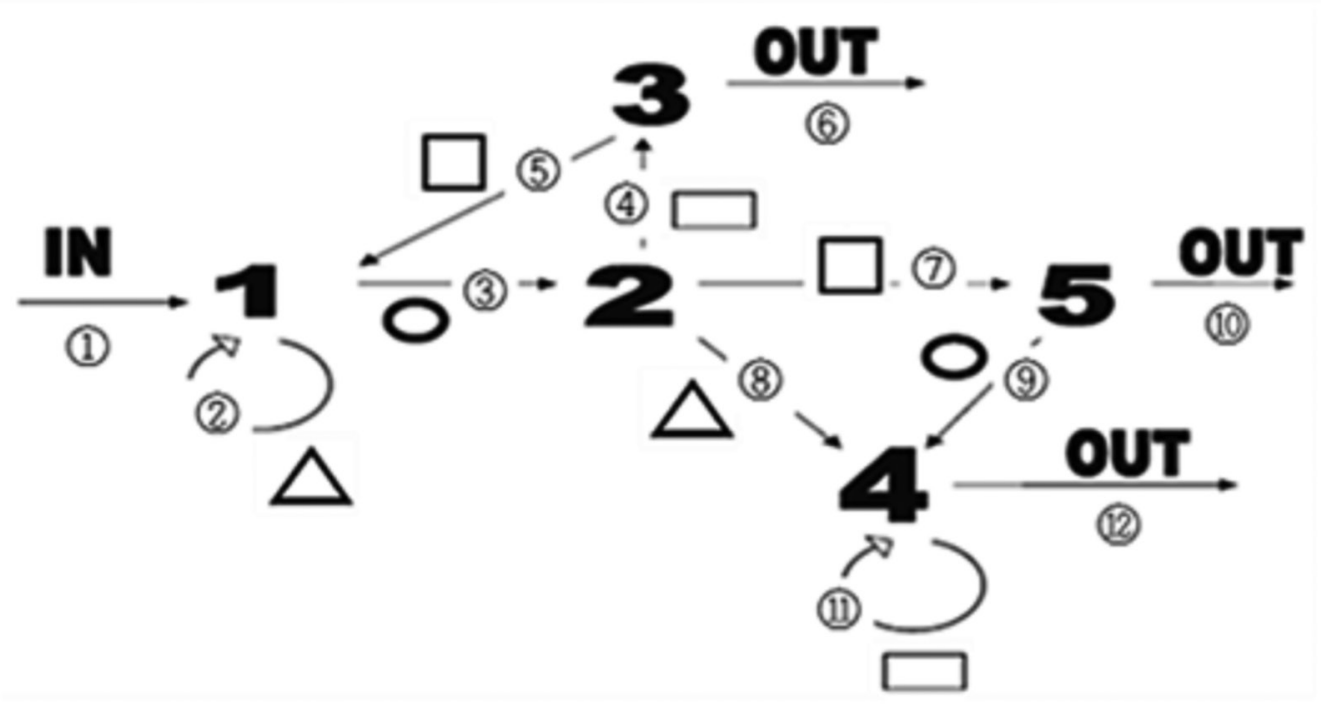

\section{Example: Grammatical Item}

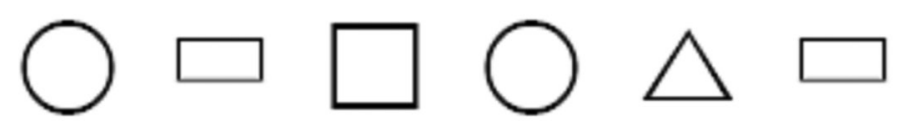

(1) $\longrightarrow$ (3) $\longrightarrow$ (4) $\longrightarrow$ (5) $\longrightarrow$ (3) $\longrightarrow$ (8) $\longrightarrow$ (11) $\longrightarrow$ (12)

Example: Non-grammatical Item

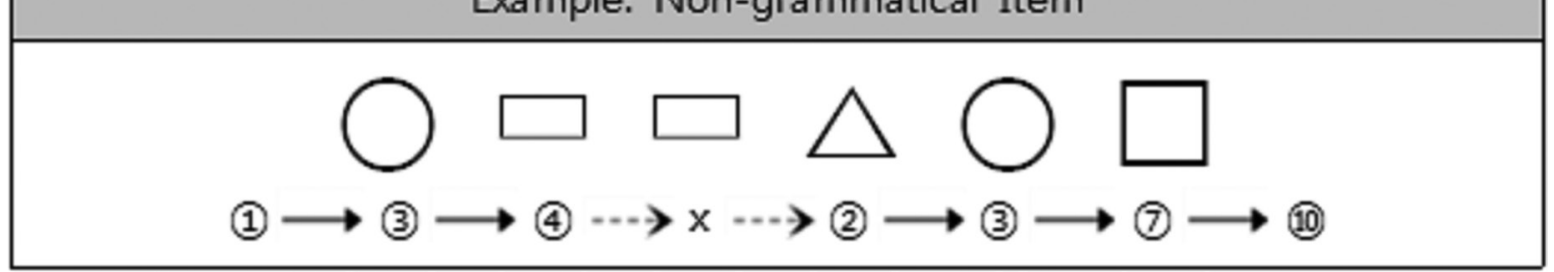

Modified from Pavlidou, Williams, \& Kelly (2009).

원래의 도형을 다음과 같이 변형함: 육각형 $\rightarrow$ 삼각형, 원 $\rightarrow$ 원, 마름모 $\rightarrow$ 정사각형, 정사각형 $\rightarrow$ 직사각형

이 모형의 규칙에 따르면, 'IN' 표시를 통해서만 도형 배열이 시작되며, ‘OUT 표시를 통해서만 배열이 끝날 수 있다. 또한 정해진 화살표의 방향에 의해 서만 다음에 올 도형이 정해진다. Pavlidou 등(2009)이 연구에서 사용한 인공 문법 모형은 육각형과 원, 마름모, 정사각형으로 이루어진 과제였다. 그 러나 본 연구에서는 비슷한 모양을 가진 기존의 도형들이 실험을 진행하는 데 있어 아동의 명시적 학습 및 암묵적 학습에 영향을 미칠 수 있기에 보다 구분이 명확한 도형으로 바꾸어 사용하였다. 
Ye Ji Park, et al. - Explicit and Implicit Learning of RD

Appendix 2. 완전 자유 회상(PFR) - 규칙 항목 카드

\begin{tabular}{|c|c|c|c|}
\hline 1 & $\begin{array}{c}\bigcirc \square \\
\triangle \bigcirc \triangle\end{array}$ & 2 & $\begin{array}{c}\bigcirc \square \\
\triangle \bigcirc \square\end{array}$ \\
\hline 3 & $\begin{array}{c}\triangle \triangle \bigcirc \square \\
\bigcirc \square \bigcirc \triangle \square\end{array}$ & 4 & $\begin{array}{c}\bigcirc \triangle \square \square \\
\triangle \triangle \triangle \bigcirc \square\end{array}$ \\
\hline 5 & $\begin{array}{l}\triangle \triangle \bigcirc \square \\
\bigcirc \triangle \square \square \square\end{array}$ & 6 & $\begin{array}{c}\triangle O \triangle \square \\
\triangle \bigcirc \triangle \square \square \square\end{array}$ \\
\hline 7 & $\begin{array}{l}\triangle \triangle \triangle O \triangle \\
\bigcirc \square \square \bigcirc \square\end{array}$ & 8 & $\begin{array}{l}\bigcirc \square \square \bigcirc \triangle \\
\triangle \triangle \bigcirc \triangle \square \square\end{array}$ \\
\hline 9 & $\begin{array}{l}\bigcirc \square \square \bigcirc \triangle \\
\triangle \bigcirc \square \square \bigcirc \square\end{array}$ & 10 & $\begin{array}{c}\triangle \bigcirc \triangle \square \square \\
\triangle \triangle \triangle \triangle \bigcirc \triangle\end{array}$ \\
\hline 11 & $\begin{array}{l}\triangle \triangle \bigcirc \triangle \square \\
\bigcirc \square \square \bigcirc \square \bigcirc\end{array}$ & & \\
\hline
\end{tabular}


Appendix 3. 규칙성 판단 - 규칙 항목 카드와 불규칙 항목 카드

\begin{tabular}{|c|c|c|c|}
\hline \multicolumn{4}{|c|}{$\begin{array}{c}\text { 규칙성 판단 } \\
\text { 븍규치 하모' } 16 \text { 개 }\end{array}$} \\
\hline \multicolumn{2}{|r|}{ 규칙 항목 } & \multicolumn{2}{|r|}{ 불규칙 항목 } \\
\hline 1 & $\triangle \bigcirc \square \bigcirc$ & 1 & $\square \triangle \bigcirc \square$ \\
\hline 2 & $\triangle \triangle \bigcirc \square \bigcirc$ & 2 & $\bigcirc \triangle \square \square \square$ \\
\hline 3 & $\triangle \triangle \bigcirc \square \bigcirc \square$ & 3 & $\triangle \triangle \square \triangle$ \\
\hline 4 & $\bigcirc \triangle$ & 4 & $\bigcirc \triangle \bigcirc \square$ \\
\hline 5 & $\bigcirc \square \bigcirc \square \square$ & 5 & $\triangle \square \square$ \\
\hline 6 & $\triangle \bigcirc \square \square \bigcirc \square$ & 6 & $\triangle \triangle \bigcirc \square \square$ \\
\hline 7 & $\triangle \bigcirc \square \bigcirc \square$ & 7 & $\triangle \triangle O$ \\
\hline 8 & $\bigcirc \square \bigcirc \square \square$ & 8 & $\triangle \bigcirc \triangle \bigcirc \square$ \\
\hline 9 & $\triangle \triangle \bigcirc \triangle \square$ & 9 & $\bigcirc \square \square \bigcirc$ \\
\hline 10 & $\bigcirc \triangle \square$ & 10 & $\bigcirc \square \square \triangle \bigcirc \square$ \\
\hline 11 & $\triangle \bigcirc \square \square \bigcirc \triangle$ & 11 & $\bigcirc \triangle \square \square \triangle$ \\
\hline 12 & $\bigcirc \square \square \triangle \bigcirc \triangle$ & 12 & $\square \bigcirc \square$ \\
\hline 13 & $\bigcirc \square \square \bigcirc \square$ & 13 & $\triangle \triangle \bigcirc \bigcirc \square$ \\
\hline 14 & $\bigcirc \square \bigcirc \square$ & 14 & $\triangle \bigcirc \triangle \square$ \\
\hline 15 & $\bigcirc \square \bigcirc$ & 15 & $\triangle \triangle \square \square$ \\
\hline 16 & $\triangle \bigcirc \square \bigcirc \square \square$ & 16 & $\triangle O \triangle O$ \\
\hline
\end{tabular}


Ye Ji Park, et al. • Explicit and Implicit Learning of RD

Appendix 4. 읽기의 하위영역과 명시적 학습능력 및 암묵적 학습능력 간의 상관 관계

\begin{tabular}{|c|c|c|c|c|}
\hline & & \multicolumn{3}{|c|}{ 인지처리능력 } \\
\hline & & 단어인지 & 읽기유창성 & 읽기이해 \\
\hline \multirow[t]{4}{*}{ 일반아동 } & 명시적 & -.751 ** & $-.661 * *$ & $-.638 * *$ \\
\hline & 학습능력 & & & \\
\hline & 암묵적 & .309 & .114 & $.559 \star$ \\
\hline & 학습능력 & & & \\
\hline \multirow[t]{4}{*}{ 읽기장애아동 } & 명시적 & -.297 & .218 & -.261 \\
\hline & 학습능력 & & & \\
\hline & 암묵적 & $.452 *$ & .140 & $.477 *$ \\
\hline & 학습능력 & & & \\
\hline
\end{tabular}

$\star p<.05, * * p<.01$. 


\section{국문초록}

\section{인공 문법 학습(AGL) 과제를 통한 읽기장애 아동의 명시적 학습능력과 암묵적 학습능력 박예지 · 김영태 \\ 이화여자대학교 언어병리학과}

배경 및 목적: 최근 들어, 읽기문제가 보편적인 인지능력의 손상에서 기인한 것이므로, 읽기 능력을 연구할 때 명시적인 학습능력과 암 묵적인 학습능력을 동시에 고찰하여야 한다는 주장이 제기되고 있다. 이에 본 연구는 인공 문법 학습(AGL) 과제를 실시하여 읽기장애 아동과 일반 아동의 명시적 학습능력 및 암묵적 학습능력에 유의한 차이가 나타나는지 살펴보려는 목적으로 수행되었다. 또한 두 학 습능력과 유의한 상관이 나타나는 읽기 관련 인지처리능력을 밝히고자 하였다. 방법: 지능 검사와 읽기 검사를 거쳐 초등학교 3-4학년 읽기장애 아동 20 명과, 생활연령 및 성별을 일치시킨 일반 아동 20 명을 연구 대상자로 선정하였다. 이후 실험과제인 인공 문법 학습은 명시적 학습능력을 알아보기 위한 완전 자유 회상 과제와암묵적 학습능력을 알아보기 위한 규칙성 판단 과제로 구성하여 실시되었다. 결과: 읽기장애 아동의 명시적 학습능력과 암묵적 학습능력이 일반 아동에 비해 통계적으로 유의하게 낮았으며, 각 학습능력과 유의 한 상관을 보인 인지처리능력 또한 집단에 따라 상이하게 나타났다. 논의 및 결론: 본 연구의 결과는 읽기장애 아동의 명시적 학습능력 의 손상은 기억 용량 결함 및 효과적인 학습전략의 부재와 연관되며, 암묵적 학습능력의 손상은 읽기장애 아동이 지니는 어려움이 보 편적인 인지 기능의 손상과 연관이 있다는 점을 시사한다.

핵심어: 인공문법학습, 읽기장애, 명시적 학습능력, 암묵적 학습능력

본 연구는 제1저자의 석사학위논문을 수정·보완한 것임.

본 연구는 정부(교육부)의 재원으로 BK21 플러스 사업의 지원을 받아 수행된 연구임.

\section{참고문헌}

곽금주, 박혜원, 김청택(2001). 한국 웩슬러 아동 지능검사-III (Korean Wechsler Intelligence Scale for Children-III). 서울: 도서출판 특수교육. 김애화(2013). 초등학생의 읽기이해 성취도에 대한 예측 변인 종단 연구: 20개월 간 추적 검사를 통하여. 언어청각장애연구, 18, 258-268.

김애화, 김의정, 황민아, 유현실(2014). 읽기 성취 및 읽기 인지처리능력 검사(Test of Reading Achievement and Reading Cognitive Processes Ability). 서울: 학지사.

김영태(2014). 아동언어장애의 진단 및 치료(제2판). 서울: 학지사.

백준오, 이선영, 김영주, 이선진(2012). 작업기억과 문법성 판단 능력의 상관관계 연구. 응용언어학, 28, 31-58. 